J. Clin. Chem. Clin. Biochem.

Vol. 26, 1988, pp. $469-475$

(C) 1988 Walter de Gruyter \& Co. Berlin - New York

\title{
Estimation of Cholinesterase Activity (EC 3.1.1.7; 3.1.1.8) in Undiluted Plasma and Erythrocytes as a Tool for Measuring In Vivo Effects of Reversible Inhibitors
}

\author{
By T. Thomsen, H. Kewitz and O. Pleul \\ Institut für Klinische Pharmakologie, Freie Universität Berlin, Klinikum Steglitz, Berlin
}

(Received November 23, 1987/April 5, 1988)

Summary: In vivo effects of reversible inhibitors of cholinesterase activity were determined radiometrically in undiluted samples of erythrocytes and plasma. $\left[{ }^{14} \mathrm{C}\right]$ acetylcholine at substrate saturation, $25^{\circ} \mathrm{C}$ and $\mathrm{pH} 7.4$ permitted rapid and precise determination of butyrylcholinesterase (EC 3.1.1.8) and acetylcholinesterase (EC 3.1.1.7) activities. Reference values for acetylcholinesterase and butyrylcholinesterase were estimated in the plasma and erythrocyte haemolysate of 102 healthy volunteers.

The time course of in vitro inhibition was monitored, starting immediately after addition of 9-amino-1,2,3,4tetrahydroacridine (tacrine), eserine or pyridostigmine to undiluted human plasma. Maximal inhibition (in vitro) was seen within $60 \mathrm{~min}$ with tacrine and eserine, in contrast to $180 \mathrm{~min}$ with pyridostigmine. The inhibition remained constant for more than $10 \mathrm{~h}$ except with eserine, from which enzyme activity showed an early recovery. Concentration response experiments were performed in undiluted human plasma and undiluted human erythrocyte haemolysate. $K_{\mathrm{i}}$-values of tacrine, eserine and pyridostigmine were estimated. In contrast to pyridostigmine and eserine, tacrine was found to have a higher affinity for butyrylcholinesterase than for acetylcholinesterase. Tacrine at $2.5 \mu \mathrm{mol} / 1$ resulted in complete inhibition of butyrylcholinesterase and $70 \%$ inhibition of acetylcholinesterase activity. Dilution of these samples up to 100 -fold was accompanied by almost complete recovery of acetylcholinesterase and by $50 \%$ recovery of butyrylcholinesterase.

\section{Introduction}

Reversible inhibitors of cholinesterase have recently gained clinical significance for the treatment of senile dementia of the Alzheimer type $(1-3)$. To monitor the effect of these inhibitors, it is necessary to estimate cholinesterases in plasma and erythrocytes. This provides an indication of the inhibition in the brain and other tissues, where it may be crucial in producing beneficial or adverse effects.

Esterase determination in the traditional way requires dilution of plasma or erythrocyte haemolysate. But the dilution may cause reactivation of the cholinesterases, which have been inhibited reversibly by potential therapeutical substances $(4,5)$. In order to measure true the inhibition, as present in vivo, it is mandatory to use a method which allows the measurement of enzyme activity without prior dilution of the samples.

In the present paper a procedure is proposed in which radiolabelled substrate is used which permits determination of the activity of butyrylcholinesterase (EC 3.1.1.8) in undiluted plasma and of acetylcholinesterase (EC 3.1.1.7) in erythrocytes without prior dilution.

\section{Materials and Methods \\ Principle of the procedure}

Acetylcholine, radiolabelled in the acetyl moiety, is split by the enzyme reaction at $25^{\circ} \mathrm{C}, \mathrm{pH} 7.4$ and at substrate saturation; the reaction is stopped by ethanol/glacial acetic acid, and the 
labelled acetic acid released by the esterase activity is evaporated, while labelled acetylcholine which has not been hydrolysed remains in the sample and can be measured. The decrease in radioactivity in the evaporated aliquots is proportional to the enzyme activity.

Substrate consumption serves as a measure of enzyme activity. Since reaction velocity remains constant (zero order reaction) only at substrate saturation, the reaction must be stopped before the decreasing substrate concentration leads to a first order reaction. Therefore, the linearity of the enzyme reaction was checked in relation to the incubation period and appropriate time intervals were established for the measurements. In agreement with previous authors $(6,7)$, a satisfactory correlation was found down to $50 \%$ of the initial substrate concentration.

\section{Chemicals, radioactive compounds, drugs}

All chemicals were commercially available and of the highest available degree of purity. $\left[{ }^{14} \mathrm{C}\right]$ acetylcholine-iodide is a product of NEN, Boston, U.S.A. Eserine and tacrine were provided by SERVA, Heidelberg, F. R. G., pyridostigmine is a product of ROCHE, Grenzach-Wyhlen, F. R. G.

\section{Preparation of samples}

Human plasma and erythrocytes were obtained from healthy male and female volunteers by venepuncture of the elbow. Coagulation was prevented by crystalline heparine; whole blood was centrifuged for 10 minutes at $2200 \mathrm{~g}$ and the plasma drawn off with a pipette. Erythrocytes were haemolyzed by freezing three times in liquid nitrogen and thawing. Samples were adjusted to $\mathrm{pH} 7.4$ prior to incubation.

\section{Incubation procedure}

In an Eppendorf micro test tube, $10 \mu$ l of substrate solution were added to $100 \mu$ l of sample material, blended immediately for 10 seconds with a mixer and subsequently incubated at $25^{\circ} \mathrm{C}$ while being shaken in a water bath (Thermomix 1460 , Braun-Melsungen, F. R. G.). Substrate concentrations were 10 $\mathrm{mmol} / \mathrm{l}$ for butyrylcholinesterase and $4 \mathrm{mmol} / \mathrm{l}$ for acetylcholinesterase in erythrocytes. $\left[{ }^{14} \mathrm{C}\right]$ acetylcholine-iodide was added to yield a specific ratioactivity of $167 \mathrm{kBq} / \mathrm{mmol}$ for the butyryl cholinesterase and of $407 \mathrm{kBq} / \mathrm{mmol}$ for the acetylcholinesterase. One sample with $100 \mu \mathrm{l}$ buffer without enzyme was used to determine the nonenzymatic hydrolysis. The enzyme activity was stopped by the addition of $1 \mathrm{ml}$ of $2 \mathrm{~g} / \mathrm{l}$ glacial acetic acid in ethanol, volume fraction 0.98 .

Samples were mixed immediately and centrifuged for 5 minutes at $10000 \mathrm{~g}$. From the supernatant, 2 aliquots of $400 \mu \mathrm{l}$ each were taken from erythrocyte samples and $500 \mu \mathrm{l}$ from plasma samples and transferred to counting vials (blank and sample). The initial value for each sample was determined directly from the first aliquot. The second aliquot was diluted with another $500 \mu \mathrm{l}$ of glacial acetic acid and subsequently taken completely to dryness in a Speed Vac Concentrator (Bachofer, Reutlingen, F. R. G.).

After evaporation of free acetic acid, the concentrated aliquots were diluted with distilled water and scintillation fluid, using the same quantities as were added to the directly measured aliquots. They were subsequently shaken twice for 10 seconds to ensure complete mixing of the radioactivity with the scintillator.

\section{Measurement of radioactivity}

All samples were carefully dissolved in $1 \mathrm{ml} \mathrm{H}_{2} \mathrm{O}$ as well as 10 $\mathrm{ml}$ of a scintillator mixture composed of $100 \mathrm{~g}$ naphtalene, $10 \mathrm{~g}$
2.5 diphenyloxazole (PPO), 0.25 g 1.4 bis-(2-4-methyl=5- phenoxazolyl) (POPOP) with 11 dioxan and measured in a betacounter (RackBeta Spektral 1219, LKB).

The difference of radioactivity between dried and non-dried aliquots is the index enzyme activity after subtraction of the nonenzymatic hydrolysis. Enzyme activity $(\mu \mathrm{mol} / \mathrm{min} \cdot \mathrm{l})$ can be calculated from the specific radioactivity $(\mathrm{Bq} / \mathrm{mmol})$ of the substrate applied, the incubation time and the amount of plasma and erythrocytes used.

\section{Results}

\section{Precision of the method}

The precision of the measuring method was tested by multiple determinations. The 20 -fold determination of a sample within one day yielded a variation coefficient $(\mathrm{CV})$ of $3.5 \%$ in human plasma and $4.5 \%$ in human erythrocyte haemolysate.

Plasma and erythrocyte samples from healthy test subjects were used to test the reproducibility on different days. Variation coefficients of $4.7 \%$ and $7.5 \%$ respectively were determined for a time span of 14 days.

\section{Linearity of the enzyme reaction}

The multiple determinations for linearity testing were individually evaluated, and the activity was plotted as difference of radioactivity against incubation time. Enzyme activity correlated well with time until almost $50 \%$ of the substrate had been hydrolysed. Results are shown in figures $1 \mathrm{a}$ and $1 \mathrm{~b}$. It can be seen that the incubation intervals used for ordinary testing, 120 seconds for plasma and 15 seconds for erythrocytes, are well in the linear range.

\section{Reference values}

Blood samples for the estimation of acetyl- and butyrylcholinesterase activities were obtained from the staff of a university hospital, Klinikum Steglitz, Freie Universität Berlin, on the occasion of a medical examination routine. 102 male and female volunteers took part, with an age of 16 to 57 years, without obvious illnesses and without intake of drugs, 14 days prior to investigation. The use of oral contraceptives, however, was no exclusion criterion but separately monitored. The median age of the females was 32 (range 16-57 years) and the median age of the males 31 (range 20-55 years).

The reference samples were evaluated according to Stamm (14). Butyrylcholinesterase activities of 2.05 $\pm 0.40(\mathrm{kU} / \mathrm{l})$ with a range of $1.34-2.77(\mathrm{kU} / \mathrm{l})$ for males and $1.92 \pm 0.40(\mathrm{kU} / \mathrm{l})$ with a range of $1.15-$ $2.71(\mathrm{kU} / \mathrm{l})$ for females were estimated. The acetyl- 

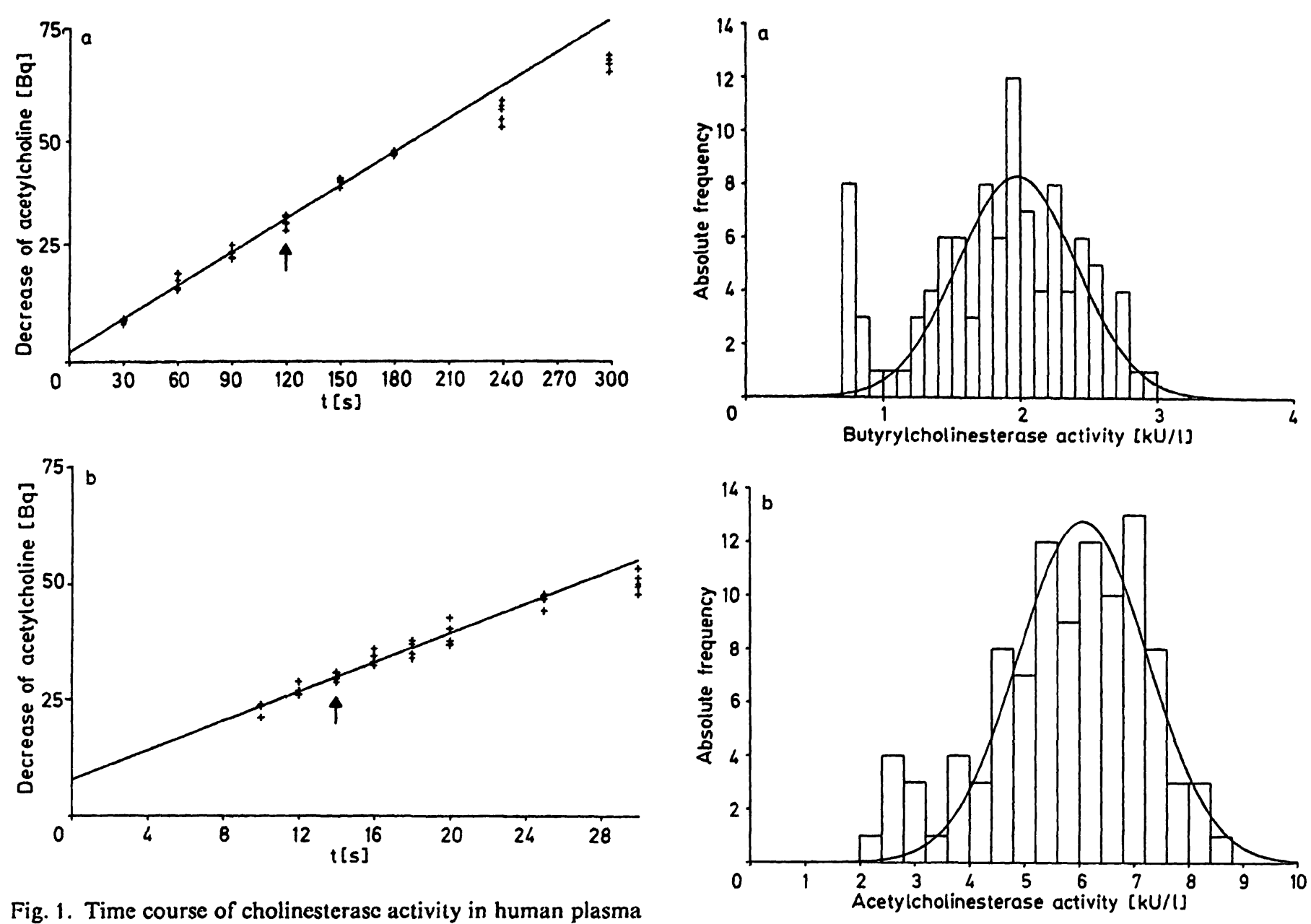

Fig. 1. Time course of cholinesterase activity in human plasma (a) and acetylcholinesterase activity in human erythrocyte haemolysate (b). Five estimations $(+)$ at each time interval. Correlation coefficient of 0.9956 (plasma) and 0.9637 (erythrocytes) calculated from values below $50 \%$ of the initial substrate concentration. The arrow marks the standard incubation time of the subsequent experiments.

Fig. 2. Frequency distribution of the enzyme activities of butyrylcholinesterase (a) and acetylcholinesterase (b) in the volunteer panel. 102 valucs are shown as histograms; the line represents the respective Gaussian curve of the data with a cut-off value of $1.0(\mathrm{kU} / \mathrm{l})$ in fig. $2 \mathrm{a}$ and $3.5(\mathrm{kU} / \mathrm{l})$ in fig. $2 \mathrm{~b}$.

cholinesterase activity was calculated as $6.14 \pm 0.95$ $(\mathrm{kU} / \mathrm{l})$ with a range of $3.93-8.25(\mathrm{kU} / \mathrm{l})$ for males and $6.00 \pm 1.18(\mathrm{kU} / \mathrm{l})$ with a range of $3.80-8.36$ $(\mathrm{kU} / \mathrm{l})$ for females.

The enzyme activities of acetylcholinesterase and butyrylcholinesterase were bimodally distributed. A first maximum of distribution was seen at 0.80 and at 2.60 $(\mathrm{kU} / \mathrm{l})$ for the butyryl- and the acetylcholinesterase, respectively, and these were not the same individuals.

Similar findings have been reported (8) for serum paraoxonase, but not yet for cholinesterases. With a cut-off value of $1.0(\mathrm{kU} / \mathrm{l})$ for the butyrylcholinesterase and. $3.5(\mathrm{kU} / \mathrm{l})$ for the acetylcholinesterase, the frequency distribution was normal and the data could be well described with a Gaussian curve (fig. $2 \mathrm{a}+$ b). The means, standard deviations and ranges of the normal values of the butyrylcholinesterasc activity were comparable to the findings of other authors, as shown in table 1.

Tab. 1. Comparison of normal values of butyrylcholinesterase catalytic activity concentration (kU/l) as reported from various authors. Substrates used were acetylcholine (our method) and acetylthiocholine (other methods).

\begin{tabular}{|c|c|c|c|c|c|c|}
\hline & \multicolumn{2}{|c|}{ Our method } & \multicolumn{2}{|c|}{ Other method 1, Prellwitz (12) } & \multicolumn{2}{|c|}{ Other method 2, Huizenga (9) } \\
\hline & $\bar{d}$ & $q$ & $\bar{d}$ & $q$ & $\delta$ & 9 \\
\hline $\begin{array}{l}\text { n } \\
\text { Mean } \\
\text { SD } \\
\text { Range }\end{array}$ & $\begin{array}{l}36 \\
2.05 \\
0.43 \\
1.3-2.9\end{array}$ & $\begin{array}{l}54 \\
1.92 \\
0.43 \\
1.1-2.8\end{array}$ & $\begin{array}{l}226 \\
2.43 \\
0.68 \\
1.3-3.7\end{array}$ & $\begin{array}{l}198 \\
2.20 \\
0.51 \\
1.2-3.2\end{array}$ & $\begin{array}{l}36 \\
3.11 \\
0.57 \\
1.8-4.4\end{array}$ & $\begin{array}{l}41 \\
2.50 \\
0.43 \\
1.6-3.5\end{array}$ \\
\hline
\end{tabular}


The butyrylcholinesterase activity was lower in females than in males, as already reported by various authors $(9-11)$. In the present work, this difference was not statistically significant, and the data are in accordance with the work of Prellwitz et al. ((12), tab. 1). No statistically significant differences were seen in the acetyl- and butyrylcholinesterase activities between women who were $(n=16)$ and those who were not $(\mathrm{n}=45)$ using oral contraceptives; this finding has already been published elsewhere for butyrylcholinesterase (11). In 10 brain areas of 23 men and 22 women post mortem, Kewitz et al. found no significant differences between sexes for the acetylcholinesterase activity (13).

\section{Stability of the samples}

The time course of inhibition by the inhibitors was determined in vitro in order to see whether enzyme activity recovers during the time interval of the experimental procedure. No relevant recovery was found in human plasma within 10 hours at $25^{\circ} \mathrm{C}$ with tacrine (fig. $3 \mathrm{a}$ ) or pyridostigmine (fig. $3 \mathrm{c}$ ), whereas a relevant/significant (concentration dependent) recovery was seen with eserine (fig. $3 \mathrm{~b}$ ). The storage of plasma samples for up to 28 days at $-20^{\circ} \mathrm{C}$ led to no significant change of enzyme activity, which agrees with the findings of other authors $(11,18)$.

\section{Kinetics of inhibition}

The kinetics of esterase inhibition were determined in vitro at $25^{\circ} \mathrm{C}$ immediately after various inhibitors at different concentrations had been added. The time interval for maximal inhibition was markedly longer at lower concentrations. The time intervals for preincubations in the subsequent concentration-response tests were accordingly adjusted and kept constant in all experiments. Preincubation periods were $60 \mathrm{~min}$ utes with eserine or tacrine and 90 minutes for pyridostigmine. Inhibition by tacrine and pyridostigmine remained constant at $25^{\circ} \mathrm{C}$ over a period of about 10 hours. An early recovery was seen with eserine, especially at lower concentrations. These findings are shown in figures $3 \mathrm{a}-\mathrm{c}$.

\section{Concentration-response curves}

Concentration-response relations with acetylcholinesterase of human erythrocytes showed $K_{\mathrm{i}}$-values of $14 \mathrm{nmol} / \mathrm{l}$ with eserine, $300 \mathrm{nmol} / \mathrm{l}$ with pyridostigmine and $630 \mathrm{nmol} / \mathrm{l}$ with tacrine. For butyrylcholinesterase, the $K_{\mathrm{i}}$-values were $21 \mathrm{nmol} / 1$ with eserine, 98 $\mathrm{nmol} / \mathrm{l}$ with tacrine and $760 \mathrm{nmol} / \mathrm{l}$ with pyridostigmine. Concentration-response curves are shown in figures $4 \mathrm{a}$ and $4 \mathrm{~b}, K_{\mathrm{i}}$-values in table 2 .
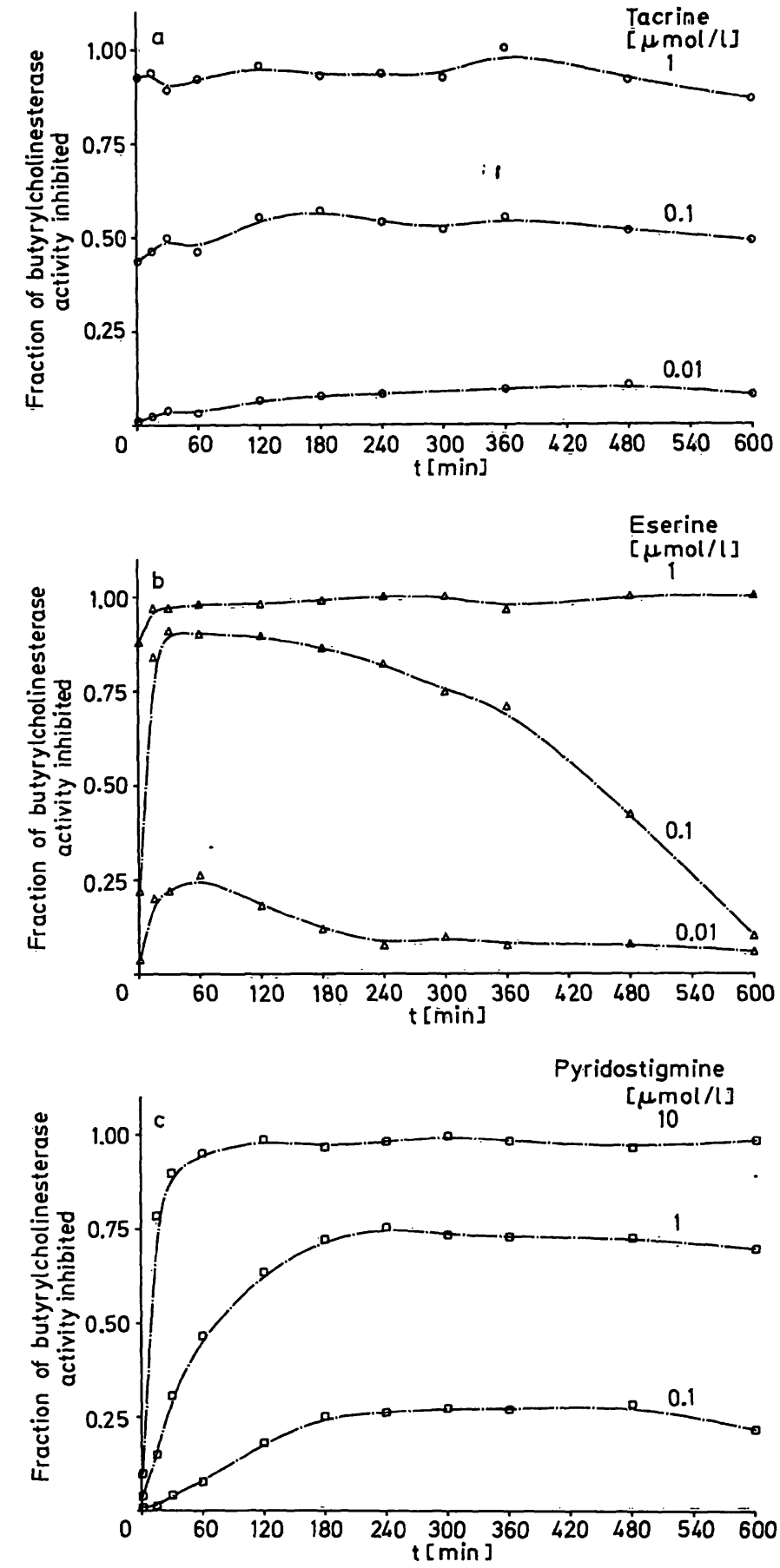

Fig. 3. Time course of enzyme inhibition in vitro (human plasma) by various inhibitors at different concentrations.

a) $1,0.1,0.01 \mu \mathrm{mol} / 1$ tacrine,

b) $1,0.1,0.01 \mu \mathrm{mol} / 1$ eserine,

c) $10,1,0.1 \mu \mathrm{mol} / 1$ pyridostigmine.

\section{Effects of dilution}

Tacrine was added to human plasma or erythrocytes in a final concentration of $2.5 \mu \mathrm{mol} / 1$. These samples were then diluted up to 100 -fold. Recovery of enzyme activity was related to concentration, and in the case of acetylcholinesterase, recovery was nearly $100 \%$ at 100 -fold dilution; at a similar dilution, the recovery of butyrylcholinesterase amounted to only $50 \%$. Results of these tests are shown in figures $5 \mathrm{a}$ and $5 \mathrm{~b}$. 

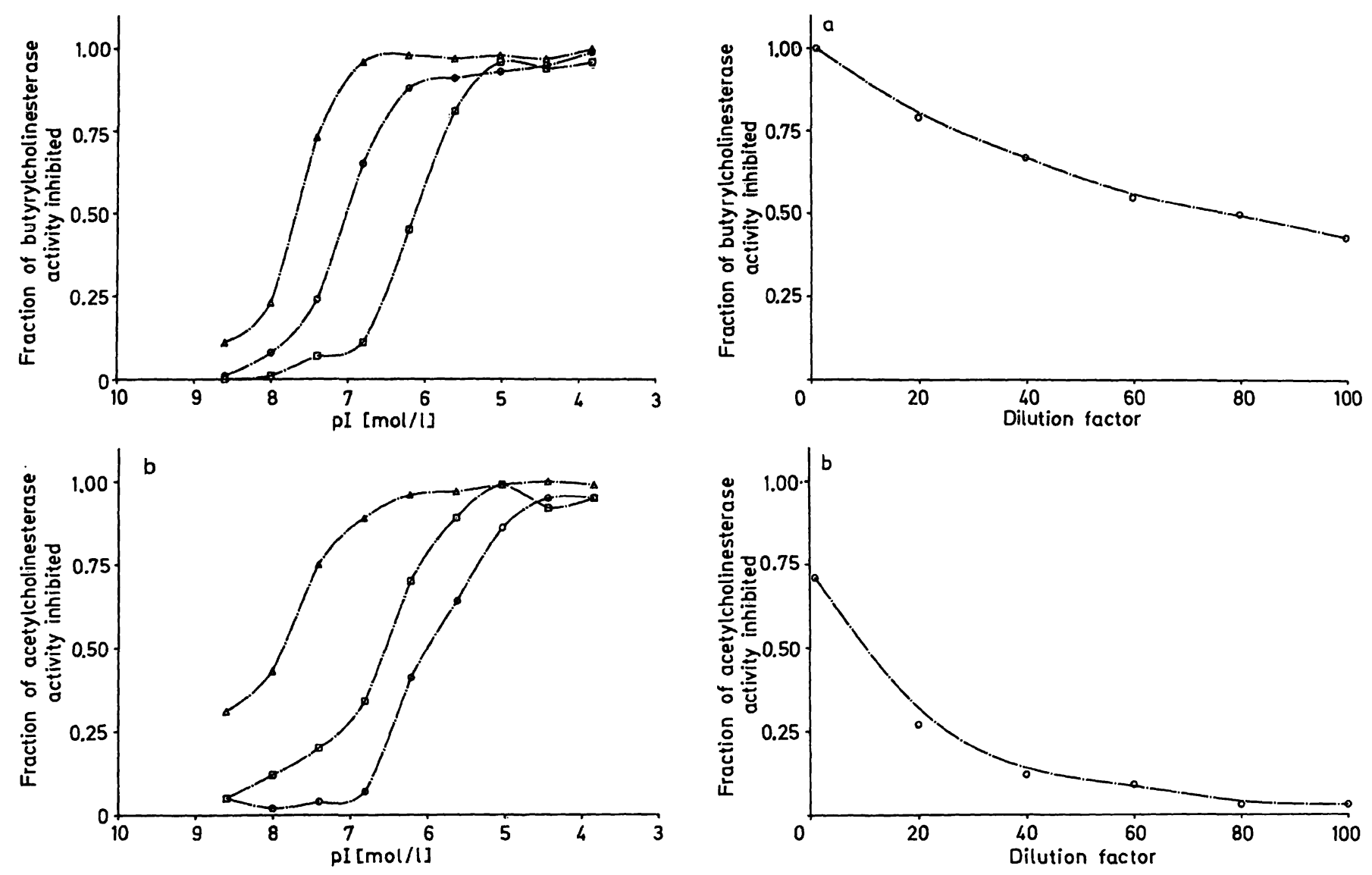

Fig. 4. Concentration-response curves of various cholinesterase-inhibitors in human plasma (a) or human erythrocytes (b). Tacrine (circles), eserine (triangles), pyridostigmine (squares). Preincubation for 60 minutes with tacrine or eserine and 90 minutes with pyridostigmine in the absence of substrate at $25^{\circ} \mathrm{C}$. Each value is the mean of two estimations. $\mathrm{pI}=-\log _{10}[\mathrm{I}]$.

Tab. 2. Comparison of the $K_{\mathrm{i}}$-values (nmol/l) of eserine, pyridostigmine and tacrine on the butyryl- and acetylcholinesterase activities.

\begin{tabular}{lcc}
\hline Substance & $\begin{array}{l}\text { Butyryl- } \\
\text { cholinesterase } \\
\text { (plasma) }\end{array}$ & $\begin{array}{l}\text { Acetylcholinesterase } \\
\text { (erythrocytes) }\end{array}$ \\
\hline Eserine & 21 & 14 \\
Pyridostigmine & 760 & 300 \\
Tacrine & 98 & 630 \\
\hline
\end{tabular}

\section{Discussion}

In principle, the activity of cholinesterases can be determined by measuring either decrease of substrate $(15-17)$ or increase of products. Products are acetic acid $(6,7,18-22)$ and choline $(10,23,24)$ or thiocholine $(11,25-28)$, if the respective artificial substrate is used.

With few exceptions $(16,17)$, the methods currently in use employ considerable dilution. Dilution of the

enzyme, however, is followed by considerable recovery from inhibition caused by reversible inhibitors. Therefore to monitor enzyme inhibition, dilution should be avoided (figs. $5 \mathrm{a}$ and $5 \mathrm{~b}$ ). The method described fullfils that requirement. The method is rapid, sensitive, precise and needs small amounts of samples only.

The measurement of the substrate consumption can be used at various substrate concentrations and also at different $\mathrm{pH}$ values and temperatures. Human erythrocytes show an activity of about $6 \cdot 10^{3} \mu \mathrm{mol} /$ min $\cdot 1$ (30) which means that $1 \mathrm{ml}$ hydrolyses more than the substrate concentration at saturation in one minute if used undiluted. It can be concluded that enzymatic hydrolysis is zero order in an undiluted sample for a few seconds only. Winteringham \& Disney (16) in 1962 introduced the measurement principle of determining the cholinesterase activities in undiluted materials by means of radiometry of unhydrolysed ${ }^{14} \mathrm{C}$-labelled acetylcholine. The precision of the method, however, was low and numerous modifications have been proposed to improve the test. 
In the procedure described in this paper, the $\mathrm{pH}$ value 7.4 was chosen to mimic physiological conditions as closely as possible. Inhibition is $\mathrm{pH}$-dependent; moreover the increase of nonenzymatic hydrolysis occurring at a more alkaline $\mathrm{pH}$ is thus largely prevented. The temperature of $25^{\circ} \mathrm{C}$ is applicable for $90 \%$ of the year and at other times it is slightly above room temperature in our climate. A lower temperature would have been favorable but would have required a more complicated cooling system. A higher temperature, on the other hand, would have reduced the short incubation time for undiluted samples even further. Various authors have stressed the significance of the preincubation time interval of inhibitors of cholinesterases in the absence of substrate for the comparability of in vitro experiments $(4,31)$.

As La Du \& Eckerson (8) described for other enzymes, the acetyl- and butyrylcholinesterase activities of our volunteer panel represented a bimodal distribution. Genetic polymorphism might have contributed to this finding, because our reference panel is not a representative part of the population and has not been screened with regard to heterozygotes or homozygotes for the atypical enzyme. It is known that phenotypes are differentiated at $25^{\circ} \mathrm{C}$, which was the standard of the present examination, more distinctly than at other incubation temperatures (32). Further investigations will be performed to verify the data.

\section{References}

1. Davies, P. (1979) Brain Res. 171, 319-327.

2. Tune, L., Gucker, S., Folstein, M., Oshida, L. \& Coyle, J. T. (1985) Ann. Neurol. 17, 46-48.

3. Collerton, D. (1986) Neuroscience 19, 1-28.

4. Foldes, F. F. \& Smith, J. C. (1966) Ann. N. Y. Acad. Sci. $135,287-301$.

5. Aldridge, W. M. (1950) Biochem. J. 46, 451-460.

6. Fonnum, F. (1975) In: Research Methods in Neurochemistry, pp. 253-275.

7. Johnson, C. D. \& Russell, R. L. (1975) Analytical Biochem. $64,229-238$.

8. La Du, B. N. \& Eckerson, H. W. (1984) Federation Proc. $43,2338-2341$.

9. Huizenga, J. R., vanderBelt, K. \& Gips, C. H. (1985) J. Clin. Chem. Clin. Biochem. 23, 283-285.

10. Panteghini, M. \& Bonora, R. (1984) J. Clin. Chem. Clin. Biochem. 22, 671-676.

11. Huizenga, J. R. \& Gips, C. H. (1987) J. Clin. Chem. Clin. Biochem. 25, 161-166.

12. Prellwitz, W., Kapp, S. \& Müller, D. (1976) J. Clin. Chem. Clin. Biochem. 14, 93-97.

13. Kewitz, H., Hanke, T. \& Hillebrand, J. (1980) Neurochem. Int. 2, 209-213.

14. Stamm, D. (1987) In: Lehrbuch der Klinischen Chemie und Pathobiochemie. (Greiling, H. \& Gressner, A. M., eds.) pp. 59-64.
From the present findings it may be concluded that the determination of substrate consumption by radioactivity measurement permits a rapid and easily reproducible determination of the acetyl- and butyrylcholinesterase activities in undiluted samples. The method is suitable for estimating the inhibition of cholinesterases by reversible inhibitors in vivo, and it is appropriate for monitoring treatment. It is known from patients with a 'silent gene', who are devoid of any butyrylcholinesterase activity, that this condition is not a life threatening factor per se (33). Additionally there is no correlation between plasma cholinesterase and erythrocyte cholinesterase, and persons with atypical plasma cholinesterase have normal erythrocyte acetylcholinesterase activities (34). Therefore the monitoring of both enzymes, acetyl- and butyrylcholinesterase is needed, particularly within a narrow therapeutic range.

\section{Acknowledgements}

The authors wish to thank Mrs $H$. Müller, Mrs G. Siebert and $\mathrm{Mr} B$. Zendeh for valuable technical assistance. Dr L. Rost provided enzyme inhibitor kinetics of tacrine and pyridostigmine. Pyridostigmine (Mestinon ${ }^{\circledR}$ ) was generously supplied by the manufacturer (Hoffmann La Roche, Grenzach-Wyhlen, F. R. G.).
15. Kalow, W. \& Lindsay, H. A. (1955) Can. J. Biochem. Physiol. 33, 568-574.

16. Winteringham, F. P. W. \& Disney, R. W. (1962) Nature $195,1303$.

17. Winteringham, F. P. W. \& Disney, R. W. (1964) Biochem. J. $91,506-514$.

18. Johnson, J. K. \& Whitehead, T. P. (1965) J. Clin. Pathol. $18,435-440$.

19. McCaman, M. W., Tomey, L. R. \& McCaman, R. E. (1968) Life Sciences 7, $233-244$.

20. Potter, L. T. (1967) J. Pharmacol. Exp. Ther. 156, 500506.

21. Reed, D. J., Boto, K. \& Wang, C. H. (1966) Analytical Biochem. 16, 59-64.

22. Siakotos, A. N., Filbert, M. \& Hester, R. (1969) Biochemical Medicine 3, 1- 12.

23. Kaneda, N., Noro, Y. \& Nagatsu, T. (1985) J. Chromatogr. $344,93-100$.

24. Okabe, H., Sagesaka, K., Nakajima, N. \& Noma, A. (1977) Clin. Chim. Acta 80, 87-94.

25. Ellman, G. L., Courtney, D. K., Andres, V. \& Featherstone, R. M. (1961) Biochem. Pharmacol. 7, 88-95.

26. Trammel, A. M., Simmons, J. E. \& Borchardt, R. T. (1984) Pharm. Res. 3, 115-120.

27. Turner, J. M., Hall, R. A., Whittaker, M. \& Kricka, L. J. (1984) Ann. Clin. Biochem. 21, 363,-365. 
28. Stieger, S., Brodbeck, U. \& Witzemann, V. (1987) J. Neurochem. 49, 460-467.

29. Ashihara, Y.. Kasahara, Y., Sugiyama, M. \& Harada, T. (1983) J. Biochem. (Tokyo) 94, 11-15.

30. Kewitz, H. \& Bitter, S. (1980) Neurochem. Int. 2, 215218.
31. Augustinsson, K. B. (1963) In: Handbuch der experimentellen Pharmakologie. Ergänzungswerk XV. (Eichler, O. \& Farah, A., eds.) pp. 106-128, Springer-Verlag, Berlin, Göttingen, Heidelberg.

32. Whittakker, M., Britten, J. J. \& Dawson, J. G. (1983) Clin. Chem. 29, 1746-1751.

33. Kutty, K. M. (1980) Clin. Biochem. 13, 239-243.

34. Williams, F. M. (1985) Clin. Pharm. 10, 392-403.

Prof. Dr. med. H. Kewilz

Institut für Klinische Pharmakologic

Freie Universität Berlin

Klinikum Steglitz

Hindenburgdamm 30

D-1000 Berlin 45 
, 